\title{
ANALISIS GEOMEKANIKA PADA BATUAN DASAR, DI AREA JS-1 RIDGE BAGIAN SELATAN, CEKUNGAN JAWA TIMUR UTARA
}

\author{
AGUNG GUNAWAN ${ }^{1}$, BENYAMIN SAPIIE ${ }^{1}$, BINTORO WIBOWO²
}

1. Program Studi Teknik Geologi, Fakultas Ilmu dan Teknologi Kebumian, Institut Teknologi Bandung (ITB), JL. Ganesha No.10, Bandung, Jawa Barat, Indonesia, 40132, Email: agunawan@skkmigas.go.id

2. PHE West Madura Offshore, Email: bintoro.wibowo@pertamina.com

\begin{abstract}
Sari - Cekungan Jawa Timur adalah salah satu cekungan penghasil hidrokarbon di Indonesia. Saat ini batuan dasar (basement) sudah mulai dievaluasi lebih detail dan dijadikan sebagai target eksplorasi. Analisis geomekanika dan tekanan rekah kritis adalah salah satu metoda yang dapat digunakan dalam melakukan evaluasi terhadap batuan dasar. Tujuannya adalah untuk mendapatkan rekahan yang berkontribusi terhadap aliran fluida di batuan dasar tersebut. Analisis rekahan dilakukan pada 2 (dua) sumur di area penelitian, yaitu Sumur-A dan Sumur-B. Dari hasil interpretasi diperoleh bahwa arah dari rekahan alami di kedua sumur tersebut adalah relatif Timur laut-Barat daya. Arah dari $\mathrm{S}_{\mathrm{H} \max }$ di Sumur B adalah Timur laut-Barat daya, tegak lurus dengan arah rekahan breakout. Arah dari $\mathrm{S}_{\mathrm{hmin}}$ di Sumur-B adalah Barat laut-Tenggara, searah dengan rekahan breakout. Dalam penelitian ini, model geomekanika hanya dilakukan di Sumur-B, karena data yang dibutuhkan untuk melakukan analisis geomekanika hanya dimiliki oleh sumur ini. Model geomekanika dari Sumur-B menunjukkan bahwa rezim tektonik di area penelitian adalah rezim strike-slip, dengan arah tegasan utama adalah Timur laut-Barat daya. Dari hasil analisis tekanan rekah kritis, rekahan yang berada pada kondisi kritis dan memiliki kemungkinan kontribusi terhadap aliran fluida adalah pada arah $\mathrm{N} 10^{\circ}-20^{\circ} \mathrm{E}$ dan $\mathrm{N} 65^{\circ} \mathrm{E}$.
\end{abstract}

Kata kunci: rekahan, geomekanika, polygon stress, tekanan rekah kritis, $\mathrm{S}_{\mathrm{Hmax}}$.

\begin{abstract}
East Java basin is one of production basin in Indonesia. Recently, basement is began evaluated more detail, and also has become one of exploration target in this area. Geomechanics and critically stress fractures analysis are some of methods which is used to evaluate basement potential. These methods are used to evaluate fractures which contribute to fluid flow in basement. Fracture interpretation is done in 2 (two) exploration well, Well-A and Well-B. The result of interpretation show the orientation of natural fracture in both wells is NortheastSouthwest (NE-SW). The orientation of $S_{H \max }$ in Well-B is Northeast Southwest (NE-SW) perpendicular to the breakout fractures. The orientation of $S_{h \min }$ in Well-B is Northwest-Southeast (NW-SE) parallel to breakout fractures. In this research, geomechanics model has only been carried out based on Well-B. The model shows that tectonic regime is strike-slip, the major stress orientation is Northeast-Southwest (NE-SW). The critically stress fracture analysis show that fracture orientation, which is in critical condition, is $N 10^{\circ}-20^{\circ} \mathrm{E}$ and $\mathrm{N} 65^{\circ} \mathrm{E}$. These fractures are considered contribute to the fluid flow in basement.
\end{abstract}

Keywords: fractures, geomechanics, stress polygon, critically stress fracture, $S_{\text {Hmax. }}$

\section{PENDAHULUAN}

Lokasi penelitian berada di Cekungan Jawa Timur Utara (offshore), tepatnya di Wilayah
Kerja Migas West Madura Offshore (Gambar 1) Jawa Timur, bersama dengan 
Bawean, Paternoster, Sulawesi Barat, dan Mangkalihat diperkirakan berasal dari bagian baratlaut Australia, disebut sebagai Argoland Terrane (Metcalfe, 2009 dalam Maulin dkk., 2012).

Cekungan Jawa Timur merupakan cekungan belakang-busur (back-arc basin) yang sangat kompleks secara struktur dan stratigrafi (Netherwood, 2000 dalam Prakasa, 2003). Dua arah struktur utama dapat dibedakan di Cekungan Jawa Timur ini (Gambar 2), yaitu patahan ekstensional berarah timurlaut-baratdaya yang relatif berada di sebelah utara, dan patahan mendatar berarah timur-barat yang relatif berada di selatan serta dikenal dengan RMK (Rembang-Madura-Kangean) atau Zona Patahan Sakala (Barraclough, 1994 dalam Satyana, 2003). Struktur berarah timurlautbaratdaya ini merupakan refleksi dari kumpulan batuan dasar yang umurnya cukup beragam, mulai dari Jura Akhir sampai dengan Kapur Akhir (Bransden dan Matthews, 1992 dalam Mudjiono dan Pireno, 2001).

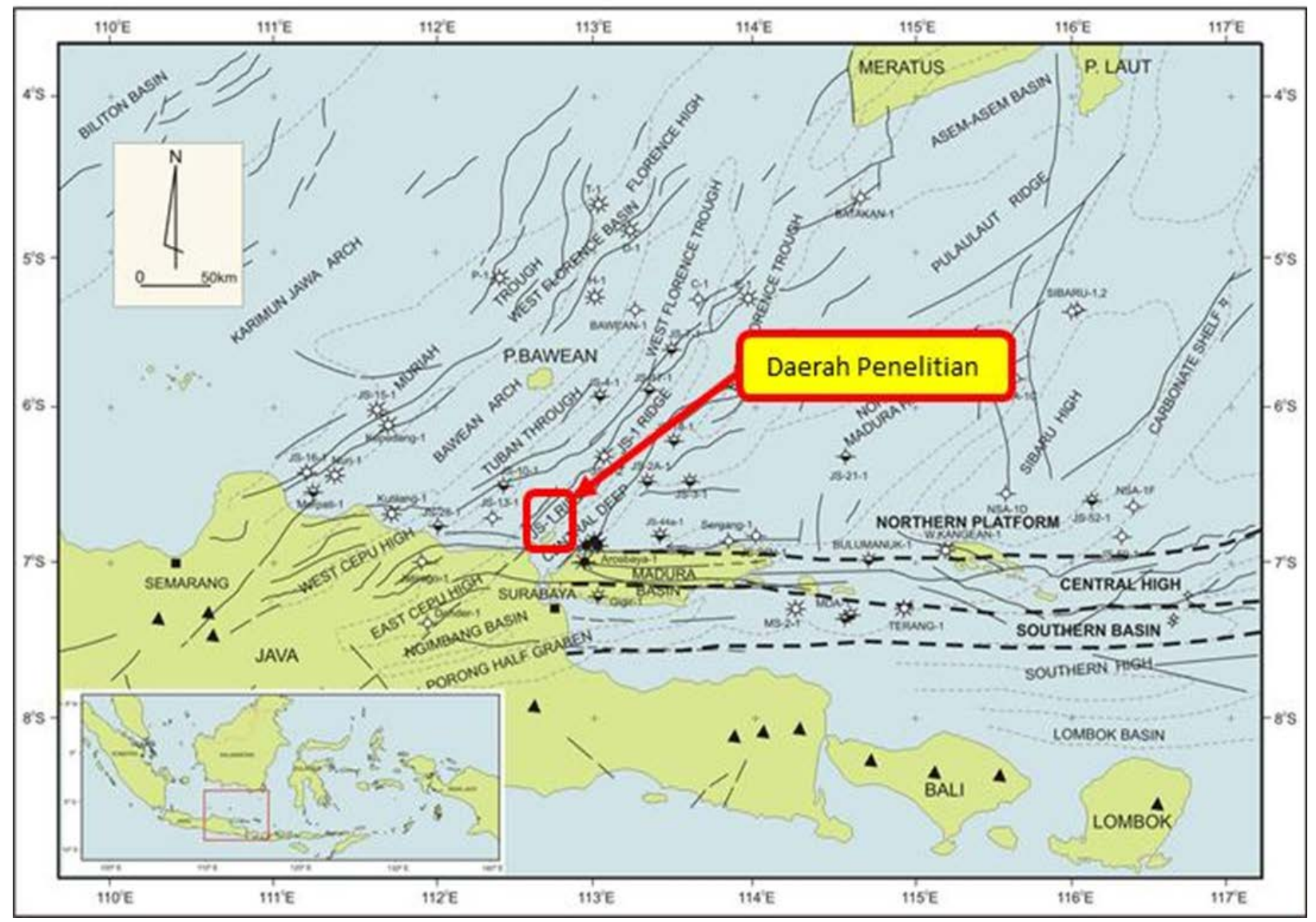

Gambar 1. Lokasi daerah penelitian ditunjukkan dalam kotak merah. 


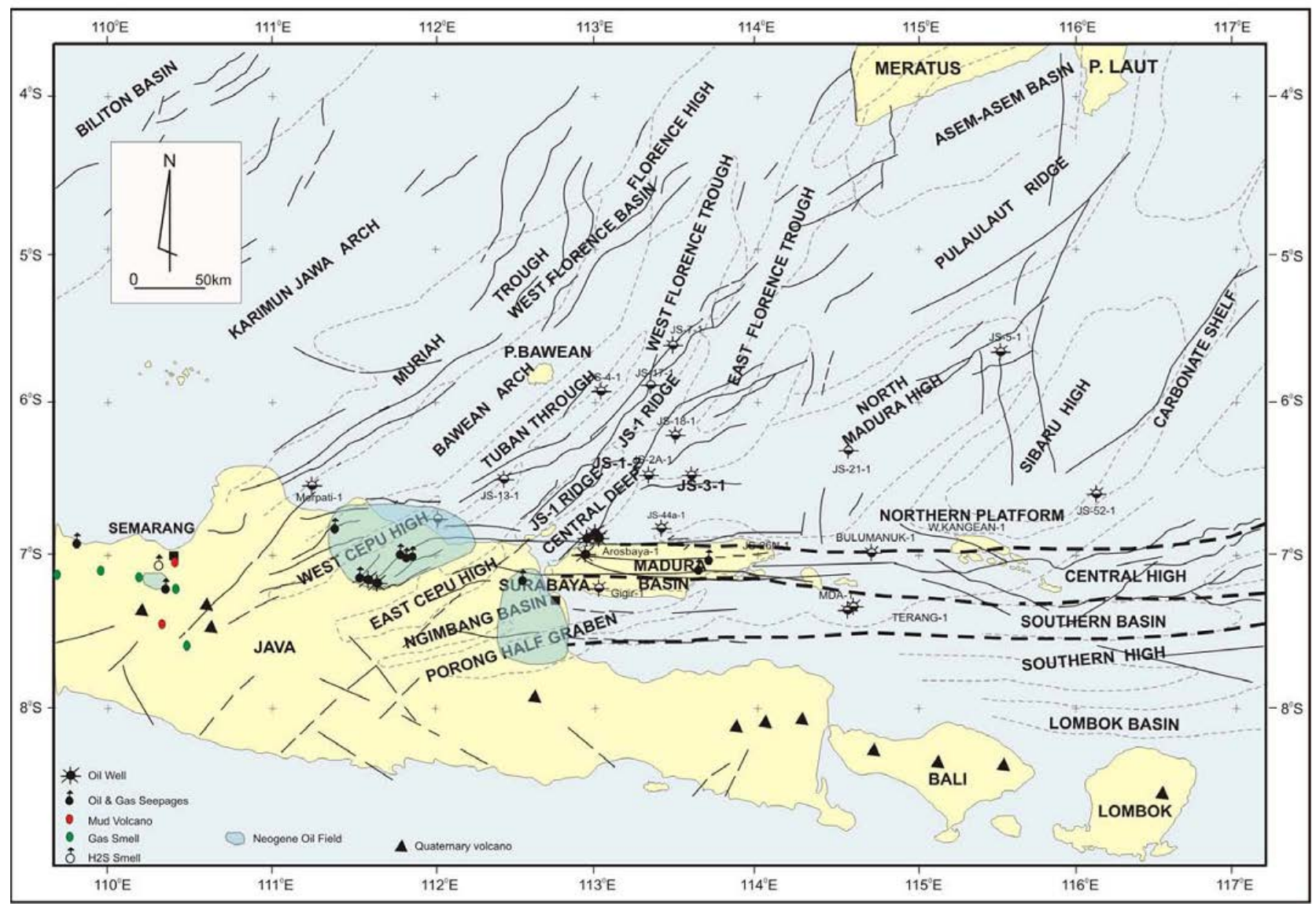

Gambar 2. Pola struktur di Cekungan Jawa Timur (Sribudiyani dkk., 2003).

Stratigrafi umum Cekungan Jawa Timur dapat dilihat pada Gambar 3. Satyana (2003) menjelaskan bahwa batuan dasar di Cekungan Jawa Timur terpisah menjadi beberapa tinggian (horst) dan dalaman (graben) dengan arah timurlaut-baratdaya. Segmentasi batuan dasar tersebut mengakomodir pengendapan sedimen synrift dan post-rift, serta perkembangan karbonat. Batuan sedimen tersebut terdiri dari batuan silisiklastik non-marine PraNgimbang, kemudian batuan non-marine sampai marginal marine Ngimbang bagian bawah yang berumur Eosen Awal-Tengah, lalu batuan yang berumur Eosen AkhirOligosen Awal terdiri dari Ngimbang bagian atas serta serpih dan karbonat "CD", selanjutnya adalah batuan silisiklastik dan karbonat Kujung yang berumur Oligosen Akhir-Miosen Awal.

Puncak dari sedimentasi karbonat adalah pada umur Miosen Awal saat pengendapan Formasi Kujung I/Tuban/OK bagian bawah dan Rancak. Kemudian tektonik inversi mempengaruhi Cekungan Jawa Timur pada umur Miosen Tengah bersamaan dengan pengendapan batupasir Ngrayong/OK bagian atas dan anggota Wonocolo bagian bawah. Sampai dengan umur Pliosen, prose transgresi dan regresi berasosiasi dengan pengendapan Formasi Wonocolo, Mundu, Paciran, dan Lidah yang terdiri dari serpih, batupasir, karbonat dan batubara. Pengaruh volkanik terjadi pada umur Plio-Pleistosen. 


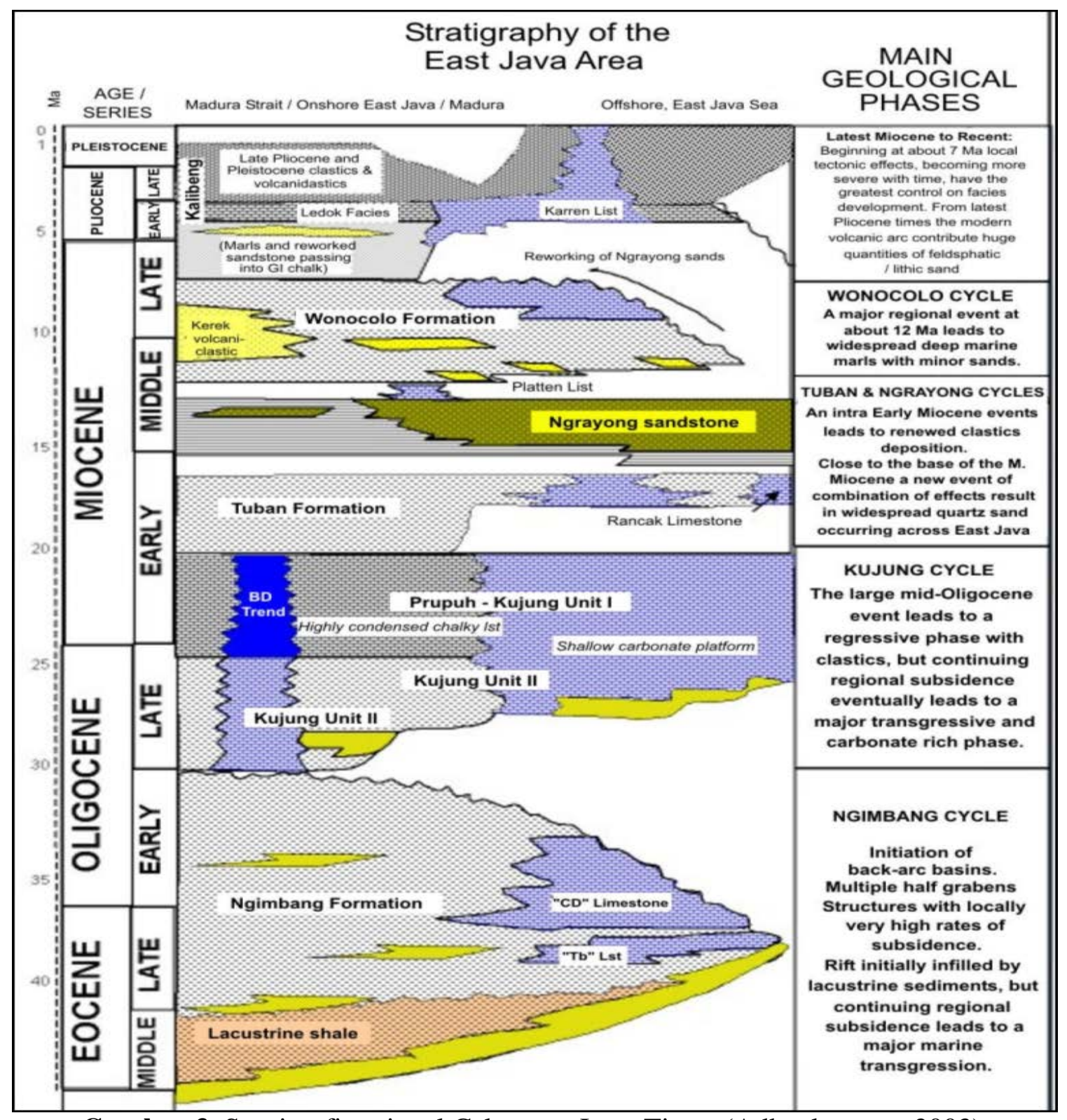

Gambar 3. Stratigrafi regional Cekungan Jawa Timur (Adhyaksawan, 2003).

\section{DATA DAN METODE}

Data yang digunakan adalah data 2 (dua) sumur eksplorasi, yaitu Sumur-A dan Sumur-B, jarak kedua sumur tersebut sekitar 4,5 km. Sumur-A menembus batuan dasar setebal 612 kaki, dan Sumur-B menembus batuan dasar setebal 743 kaki. Litologi batuan dasar yang ditembus oleh kedua sumur tersebut adalah batuan metamorfik (kuarsit).

Metode yang digunakan dalam penelitian ini adalah deterministik dengan beberapa asumsi (Gambar 4). Hal pertama yang dilakukan adalah melakukan interpretasi rekahan pada log gambar (image log) di Sumur-A dan B. 


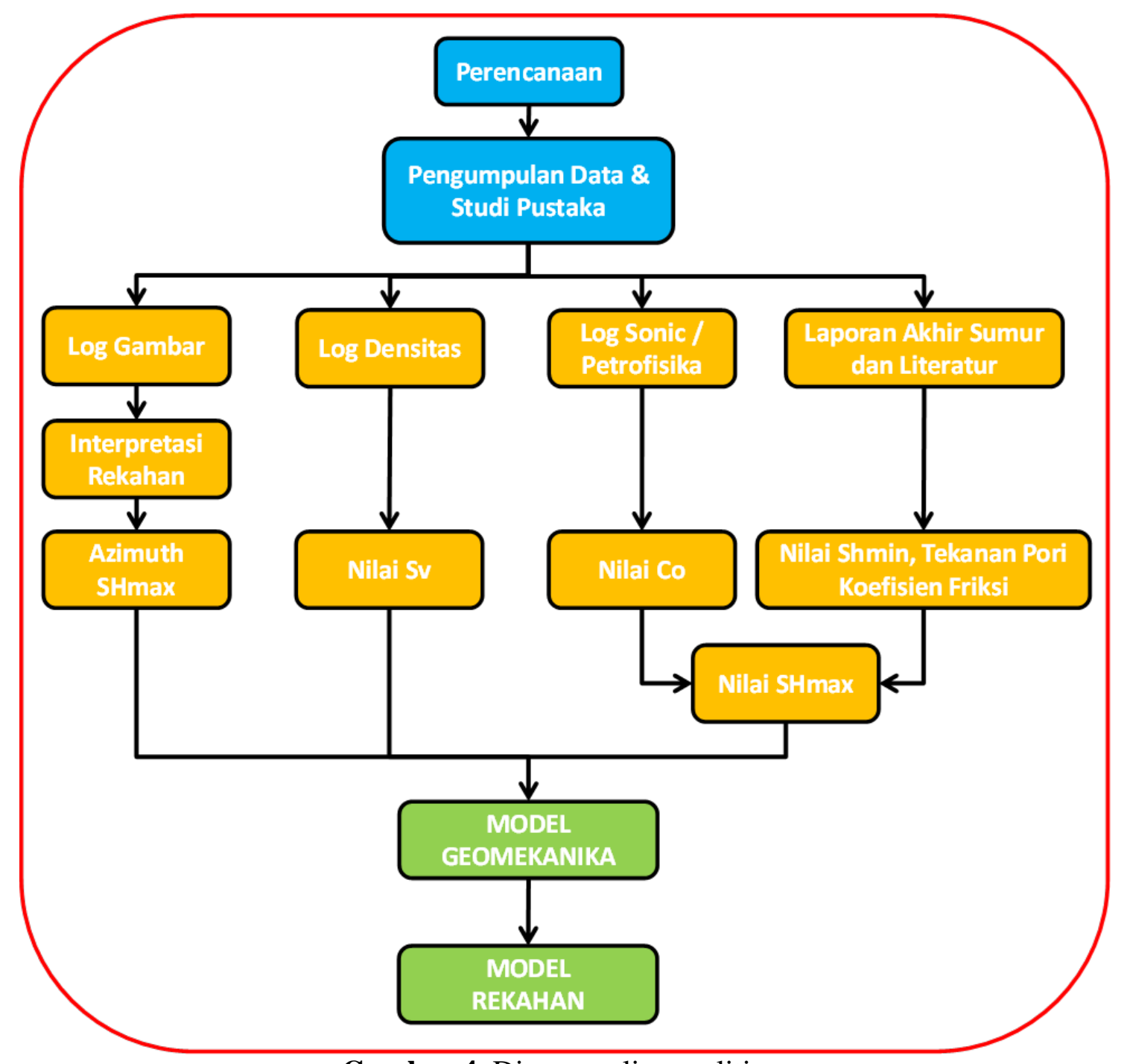

Gambar 4. Diagram alir penelitian.

Kemudian hal selanjutnya yang dilakukan adalah menentukan nilai/besaran dari setiap parameter geomekanika, yaitu SHmax, Shmin, Sv, Tekanan pori (Pp), kekuatan batuan (Co), dan koefisien friksi $(\mu)$. Nilai tegasan vertikal (Sv) diperoleh dari data log densitas, kemudian nilai kekuatan batuan (Co) diperoleh berdasarkan kalkulasi menggunakan log sonic/data petrofisika dikarenakan tidak ada pengukuran langsung yang dilakukan baik di Sumur A maupun B. Nilai tekanan pori (Pp) diperoleh dari data log tekanan. Nilai SHmax dan Shmin diperoleh dengan menggunakan stress polygon, serta nilai koefisien friksi ( $\mu$ ) diperoleh dari literatur.

Selanjutnya adalah membuat model geomekanika dengan menggunakan nilai dari setiap parameter geomekanika yang sudah diperoleh sebelumnya. Hal terakhir yang dilakukan adalah menentukan arah rekahan yang berada dalam kondisi tekanan kritis menggunakan Diagram MohrCoulomb. 


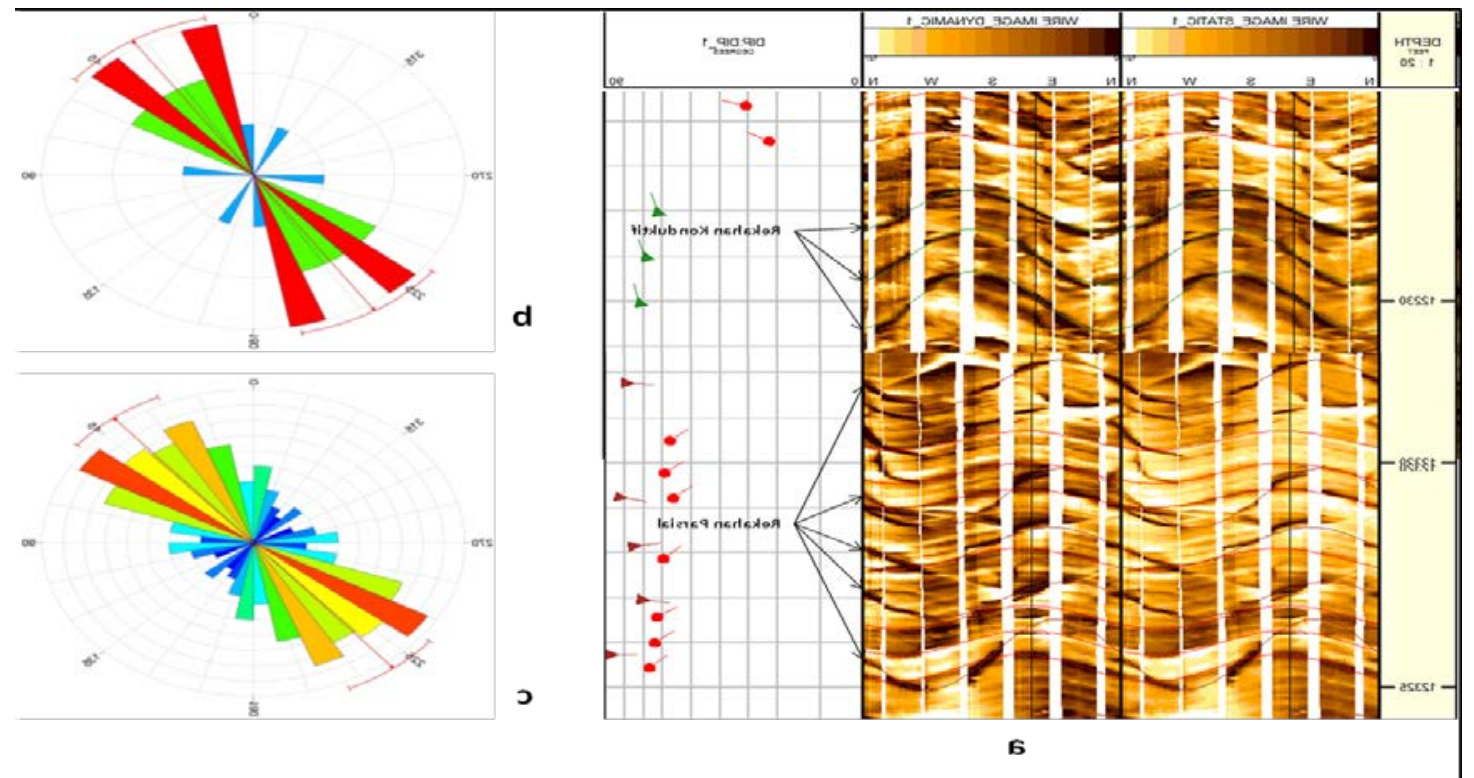

Gambar 5. (a) Interpretasi rekahan pada Sumur A dan B, (b) Diagram roset rekahan konduktif dan parsial Sumur-A, (c) Diagram roset rekahan konduktif dan parsial Sumur-B.

\section{INTERPRETASI DAN HASIL Rekahan}

Interpretasi rekahan dilakukan pada log gambar di Sumur-A dan B. Interpretasi dilakukan untuk rekahan alami dan rekahan akibat pengeboran. Jumlah rekahan alami konduktif dan parsial yang diinterpretasi di Sumur-A adalah sebanyak 15 rekahan, dengan intensitas 1 rekahan setiap 28 kaki. Hasil dari interpretasi rekahan di sumur ini diperoleh kemiringan dominan $30^{\circ}-40^{\circ}$, dan jurus bidang rekahan dominan adalah antara $\mathrm{N} 10^{\circ} \mathrm{E}-\mathrm{N} 50^{\circ} \mathrm{E}$. Jumlah rekahan konduktif dan parsial yang diinterpretasi di Sumur-B adalah sebanyak 166 rekahan, dengan intensitas 1 rekahan setiap 25 kaki. Hasil dari interpretasi rekahan di sumur ini diperoleh kemiringan dominan $50^{\circ}-60^{\circ}$, dan jurus bidang rekahan dominan adalah antara $\mathrm{N} 20^{\circ} \mathrm{E}-\mathrm{N} 60^{\circ} \mathrm{E}$ (Gambar 5).

Rekahan induced tensile yang diperoleh dari hasil interpretasi di Sumur-B adalah 33 buah rekahan. Arah dominan dari rekahan induced tensile ini adalah relatif Timur Laut-
Barat Daya (NE-SW), dengan arah yang dominan antara $\mathrm{N} 220^{\circ} \mathrm{E}-\mathrm{N} 230^{\circ} \mathrm{E}$. Rekahan breakout yang diperoleh dari hasil interpretasi di Sumur-B adalah 15 buah rekahan. Arah dominan dari rekahan berakout ini adalah relatif Barat LautTenggara (NW-SE), dengan arah yang dominan antara N120 $\mathrm{E}-\mathrm{N} 130^{\circ} \mathrm{E}$ dan $\mathrm{N} 300^{\circ} \mathrm{E}-\mathrm{N} 310^{\circ} \mathrm{E}$ (Gambar 6).

\section{Tekanan Pori $\left(\mathbf{P}_{\mathrm{p}}\right)$}

Data tekanan pori dari Sumur-A diperoleh dari pengukuran tekanan langsung di lubang bor (RDT). Untuk nilai tekanan di batuan dasar, diperoleh dari hasil tes di zona batuan dasar, semakin ke bawah terlihat separasi antara garis tekanan hidrostatik dengan mudweight sedikit melebar, hal ini juga dikonfirmasi data bacaan gas yang lebih tinggi dibandingkan dengan bacaan gas di atasnya, namun nilai tekanan dari data tes memperlihatkan tekanan di batuan dasar mendekati pada kondisi hidrostatik (Gambar 7). 


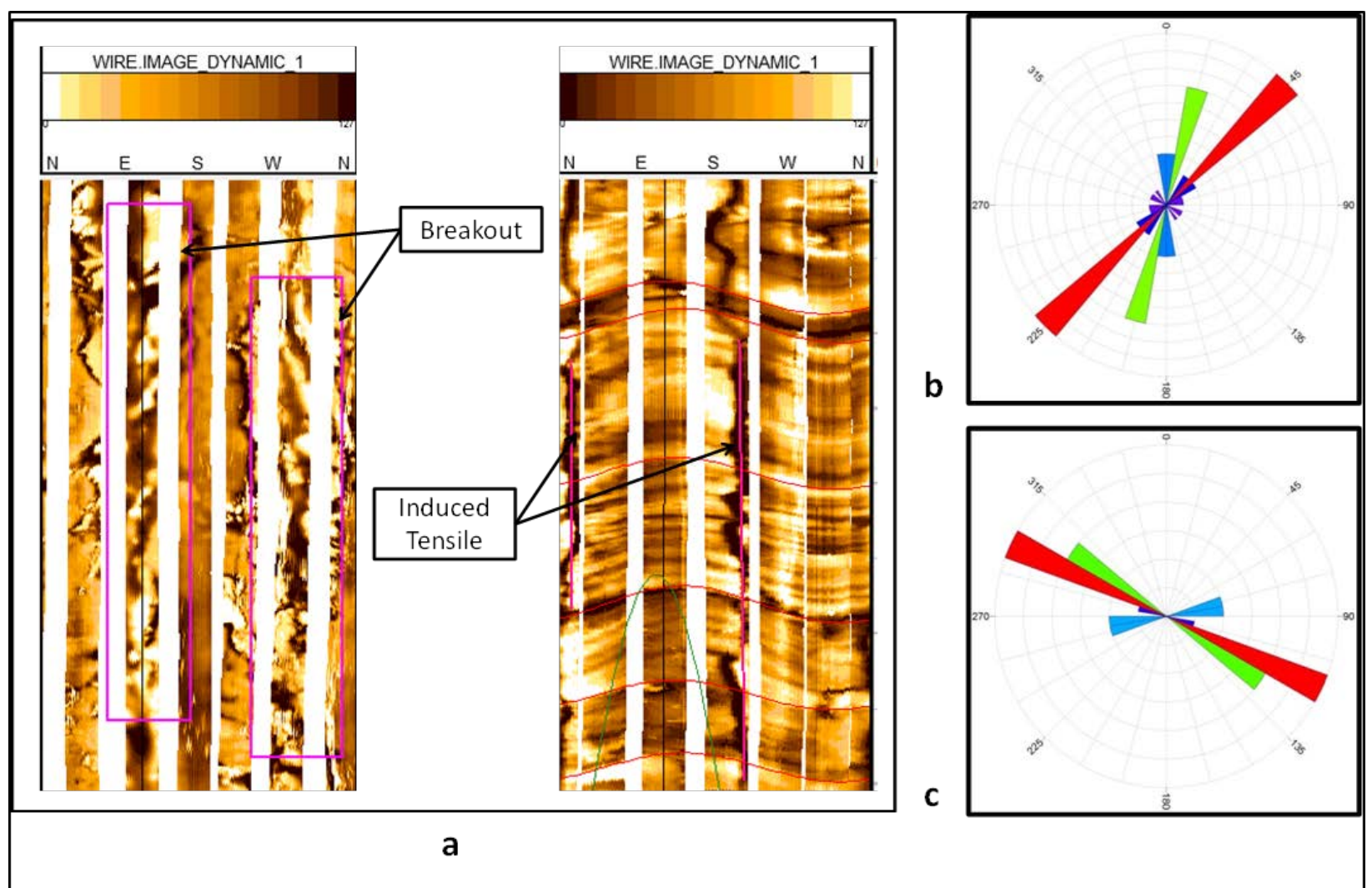

Gambar 6. (a) Interpretasi rekahan breakout dan induced tensile di Sumur-B, (b) Diagram roset rekahan induced tensile Sumur-B, (c) Diagram roset rekahan breakout Sumur-B.

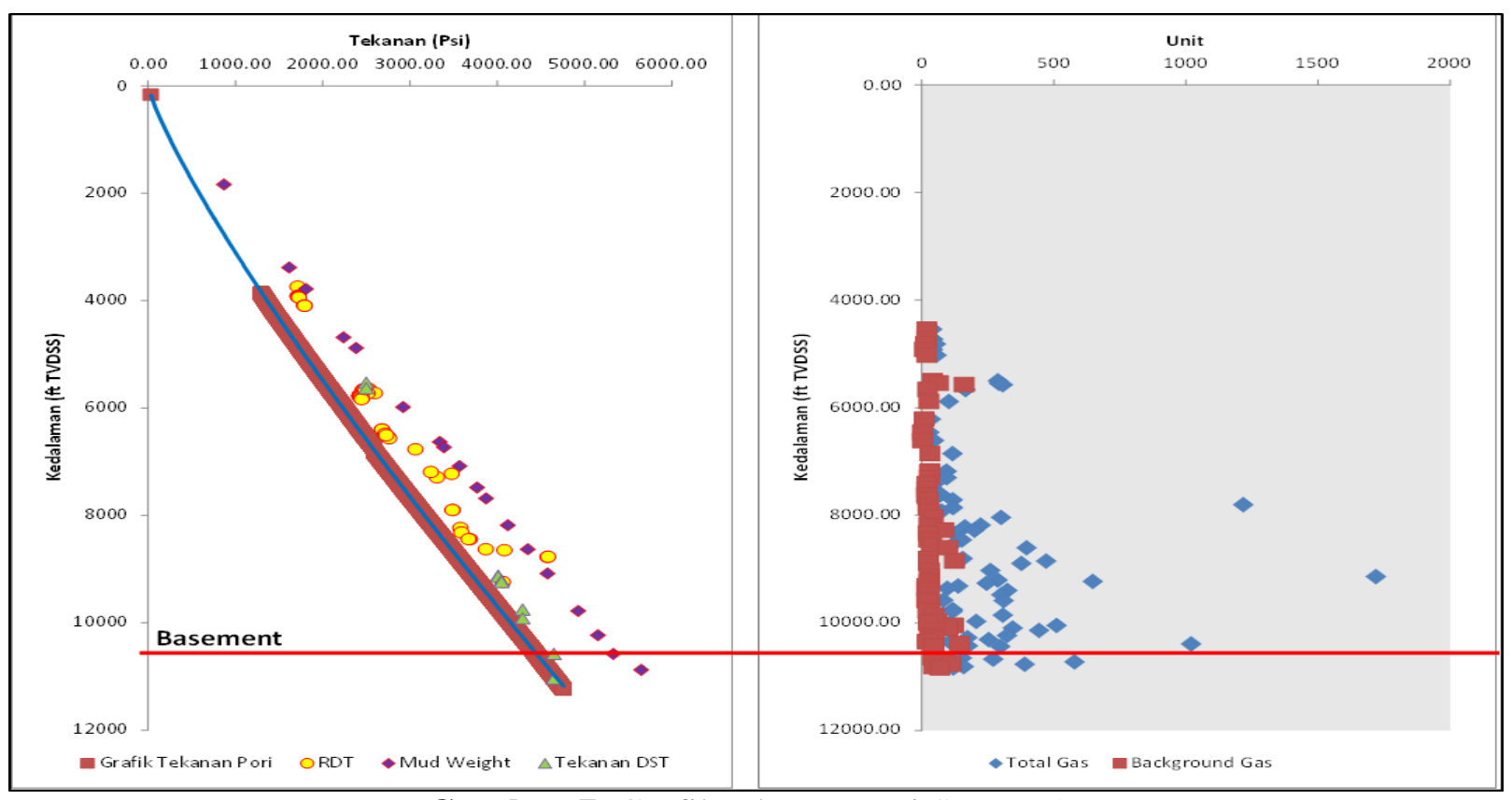

Gambar 7. Grafik tekanan pori Sumur-A. 


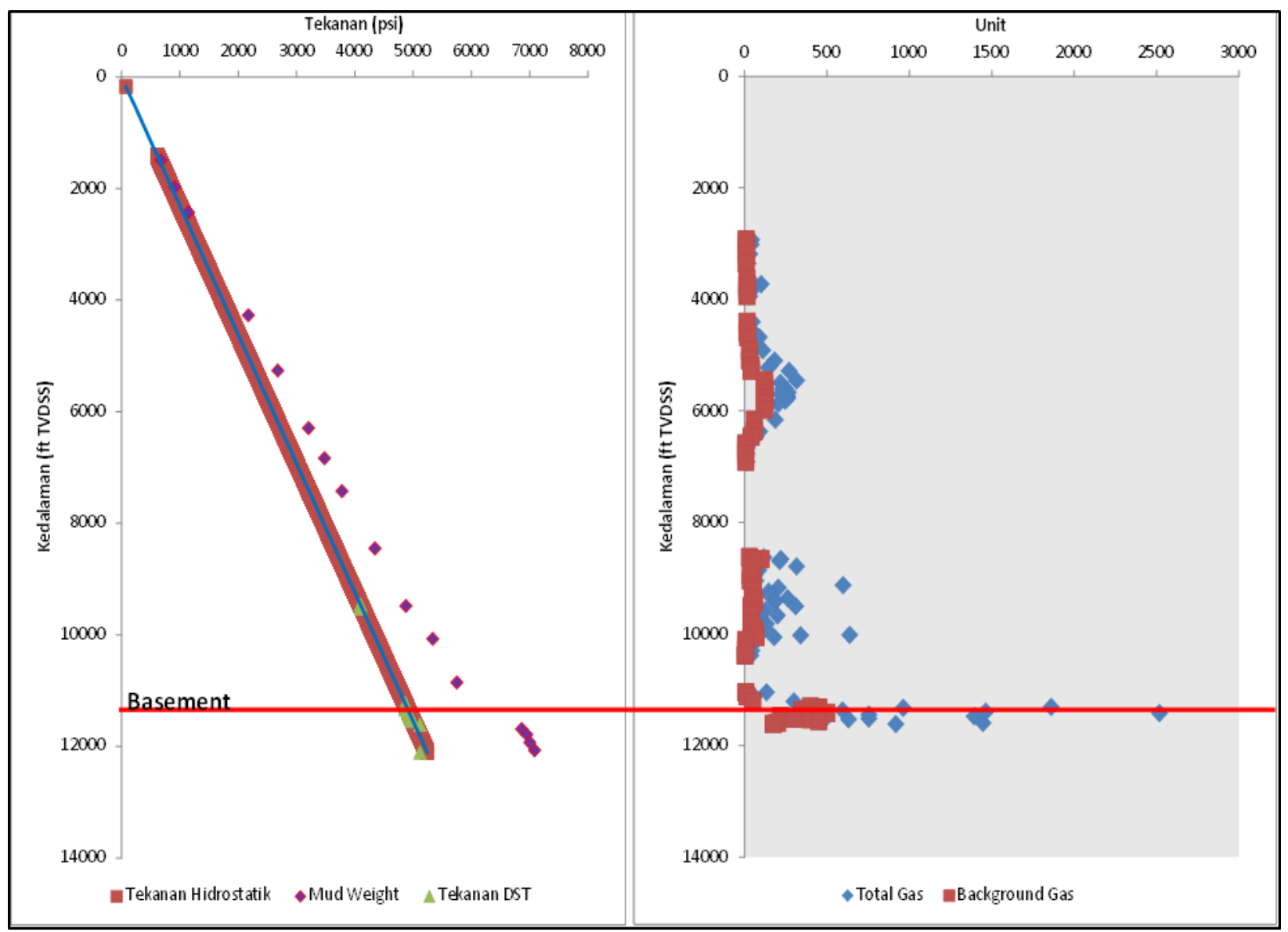

Gambar 8. Grafik tekanan pori Sumur-B.

Estimasi tekanan pori untuk Sumur-B dilakukan dengan menggunakan data berat lumpur pengeboran, karena tidak dilakukan pengukuran data tekanan langsung pada saat

pengeboran berlangsung. Selain itu digunakan juga data tekanan yang diperoleh dari hasil tes sumur.

Bacaan gas yang cukup tinggi direspon dengan berat lumpur yang lebih tinggi, namun data tekanan dari hasil tes tidak memperlihatkan hal tersebut (Gambar 8).

\section{Tegasan Vertikal $\left(\mathrm{S}_{\mathrm{v}}\right)$}

Tegasan vertikal dikenal juga sebagai tegasan overburden, tegasan ini dipengaruhi oleh nilai densitas, percepatan gravitasi, serta kedalaman. Dengan kata lain tegasan vertikal adalah fungsi kedalaman dari densitas dan percepatan gravitasi

$$
S_{v}=\int_{0}^{z} \rho \cdot g \cdot d z
$$

Sumur-A dan B adalah sumur di lepas pantai (offshore), sehingga nilai tegasan vertikal untuk masing-masing sumur ditambahkan dengan tebalnya kolom air di masingmasing lokasi (Gambar 9). Dari grafik diperoleh gradient tegasan vertikal di Sumur-A adalah 1,09 psi/ft, dan di Sumur-B adalah 1,06 psi/ft. 


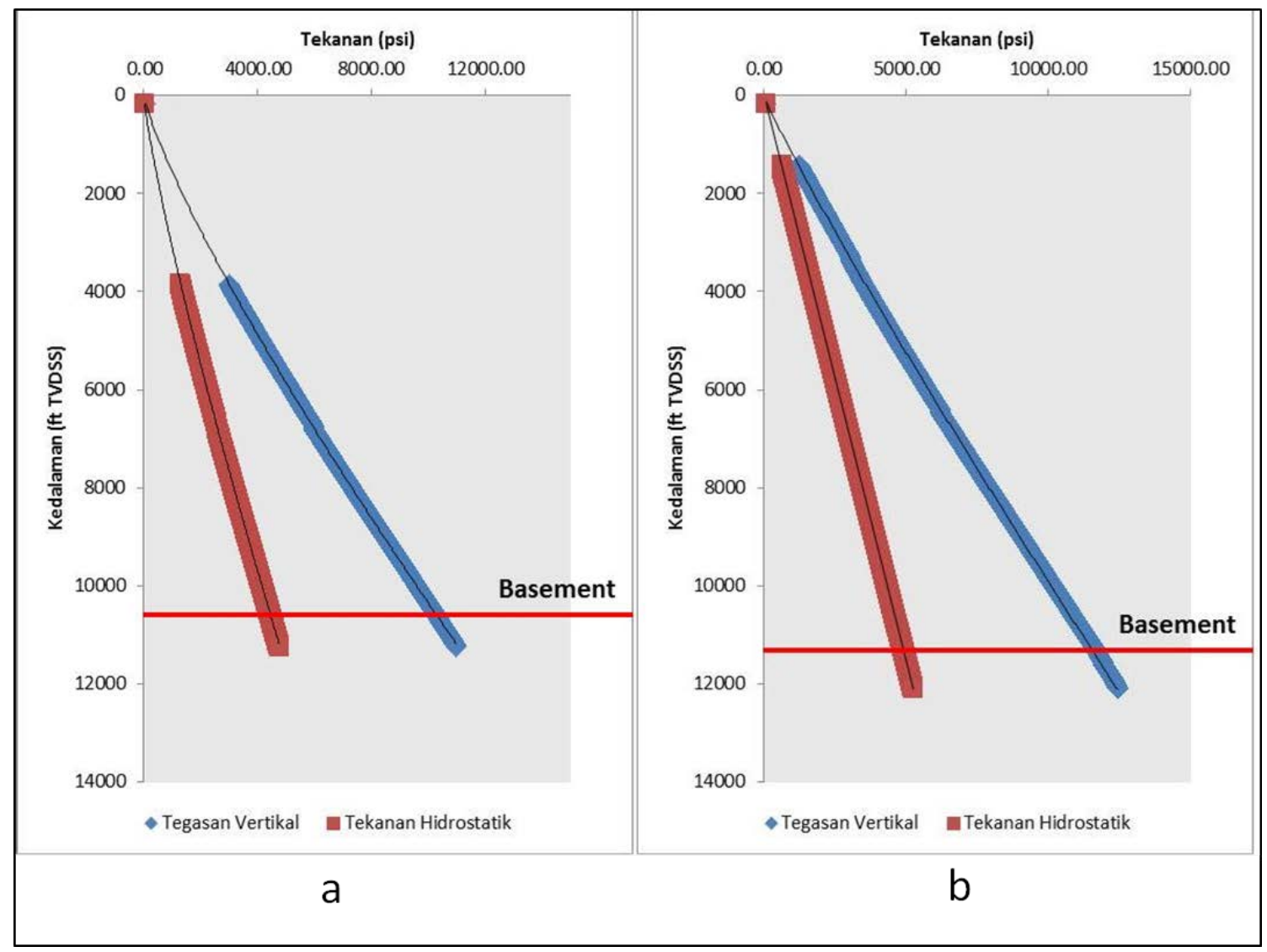

Gambar 9. Grafik tegasan vertikal $\left(S_{v}\right)$ (a) Sumur-A, (b) Sumur-B.

\section{Kekuatan Batuan $\left(\mathrm{C}_{0}\right)$}

Kekuatan batuan didefinisikan sebagai kemampuan batuan untuk menahan deformasi dari luar ketika tegasan dari luar diberikan pada batuan tersebut. Nilai kekuatan batuan umumnya diperoleh dari pengukuran inti bor di laboratorium, Namun di dalam penelitian ini tidak didapatkan inti batuan baik dari Sumur-A maupun SumurB.

Nilai kekuatan batuan pada penelitian ini diperoleh melalui pendekatan dengan menghitung nilai kekuatan batuan menggunakan data geofisika (log). Persamaan yang digunakan untuk menghitung kekuatan batuan dasar di penelitian ini adalah persamaan dari Annor dan Jackson (1987), yaitu:

$$
C_{o}=129+(14,5 \mathrm{Vp})
$$

Nilai Vp yang digunakan adalah menggunakan data velocity dari VSP. Dari hasil persamaan tersebut diperoleh nilai ratarata kekuatan batuan untuk batuan dasar di Sumur-B adalah 201,02 MPa (29.156,05 Psi).

\section{Tegasan Horizontal Minimum ( $\left.\mathrm{S}_{\text {hmin }}\right)$}

Arah dari $\mathrm{S}_{\text {hmin }}$ dapat diperoleh dari rekahan induced tensile dan breakout. Dalam penelitian ini arah dari tegasan horizontal minimum, yaitu relatif Barat Laut-Tenggara (NW-SE), parallel dengan arah rekahan breakout (Gambar 10). 


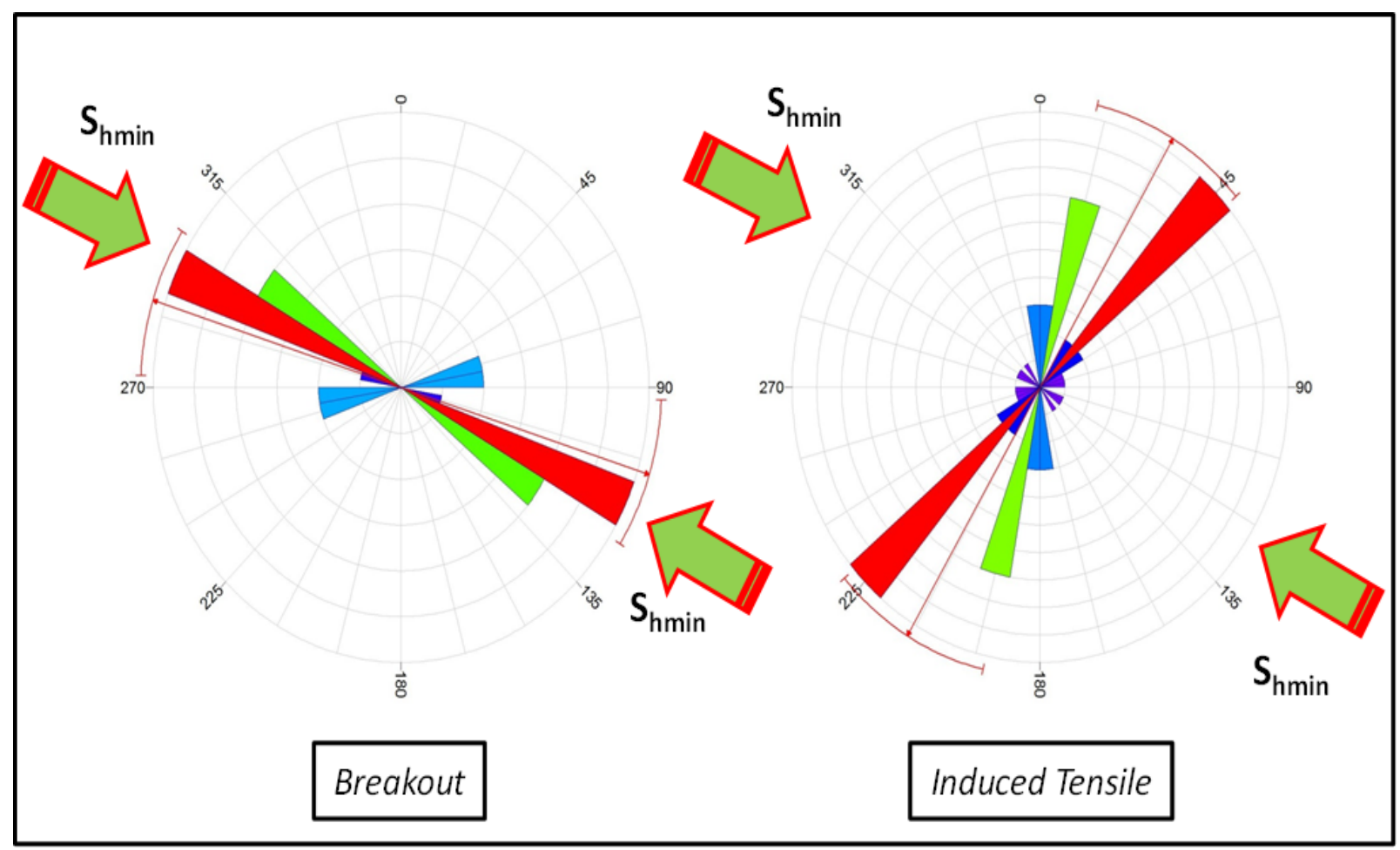

Gambar 10. Interpretasi arah tegasan horizontal minimum $\left(\mathrm{S}_{\mathrm{hmin}}\right)$ di Sumur-B.

Estimasi nilai tegasan horizontal minimum di Sumur-A menggunakan data FIT. Berdasarkan data tersebut, gradien estimasi nilai tegasan horizontal minimum adalah gradien $0,78 \mathrm{psi} / \mathrm{ft}$. Nilai estimasi ini mungkin akan lebih kecil dibandingkan dengan nilai tegasan horizontal minimum yang sebenarnya, karena nilai FIT hanya mengukur kekuatan batuan sesuai dengan asumsi, namun tidak sampai pada tahap batuan tersebut pecah (failure).

Data yang digunakan untuk melakukan estimasi besaran tegasan horizontal minimum di Sumur-B adalah data leak-off test (LOT). Terdapat 3 (tiga) titik pengambilan data LOT di Sumur-B. Berdasarkan data tersebut diperoleh nilai gradien untuk nilai tegasan horizontal minimum di Sumur-B adalah 0,78 psi/ft (Gambar 11).
Tegasan Horizontal Maksimum ( $\mathrm{S}_{\text {Hmax }}$ )

Seperti halnya $\mathrm{S}_{\mathrm{hmin}}$, arah dari $\mathrm{S}_{\mathrm{Hmax}}$ juga diperoleh dari data rekahan breakout dan induced tensile. Arahnya akan saling tegak lurus dengan arah $\mathrm{S}_{\mathrm{hmin}}$. Dari hasil analisis rekahan, arah dari $\mathrm{S}_{\text {Hmax }}$ adalah Timur LautBarat Daya (NE-SW), paralel dengan arah rekahan induced tensile (Gambar 12).

Nilai dari tegasan horizontal maksimum ( $\mathrm{S}_{\text {Hmax }}$ ) dapat diperoleh dari persamaan berdasarkan keterdapatan rekahan breakout atau induced tensile pada lubang bor (Zoback, 2007). Nilai $S_{\text {Hmax }}$ yang diperoleh dari rekahan breakout diperoleh dengan persamaan:

$$
S H \max =\frac{\begin{array}{c}
\left(C_{o}+2 P_{p}+\Delta P+\sigma^{\Delta T}\right)- \\
\operatorname{Shmin}(1+2 \cos 2 \theta b)
\end{array}}{(1-2 \cos 2 \theta b)}
$$




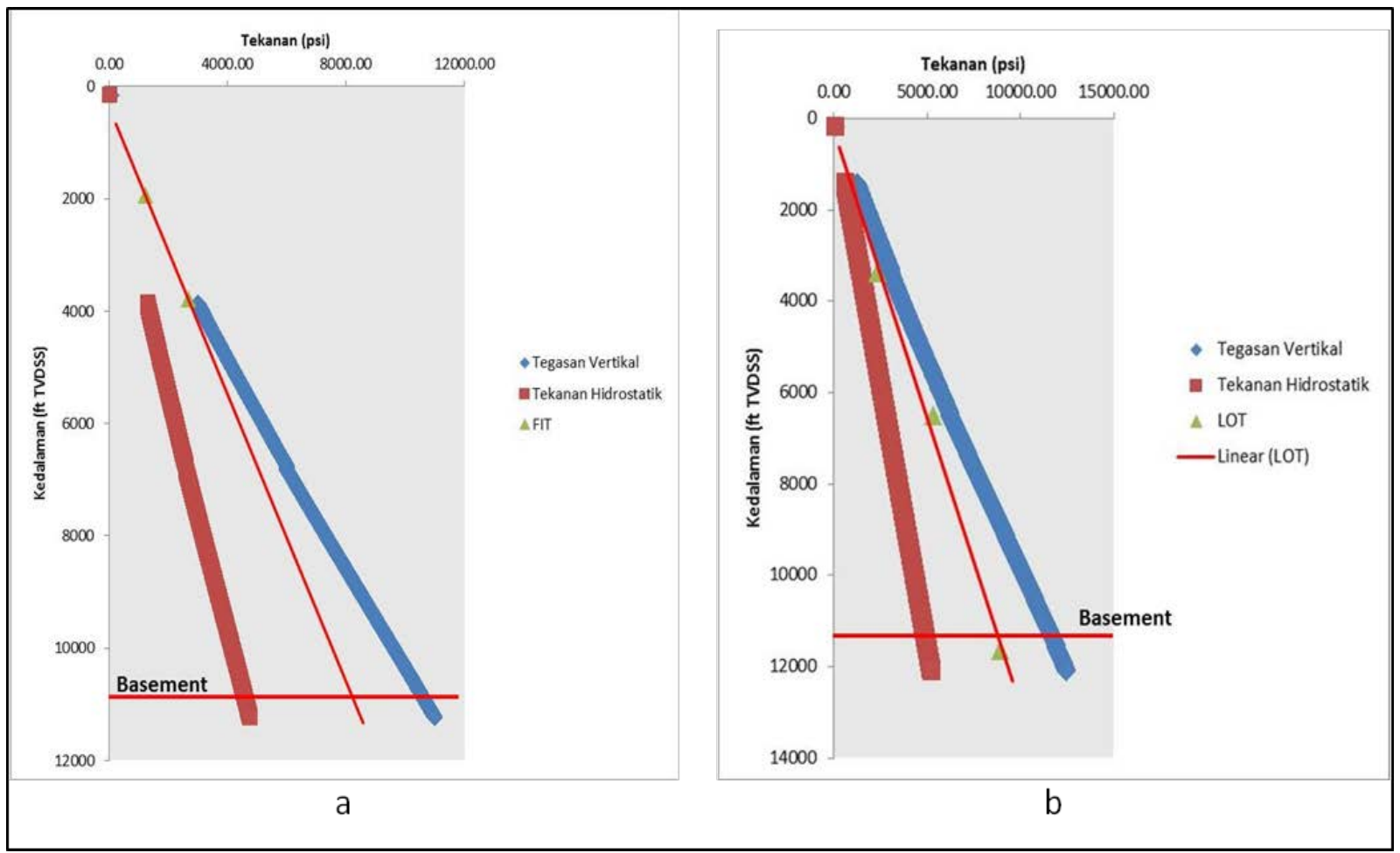

Gambar 11. Interpretasi nilai tegasan horizontal minimum ( $\left.S_{h m i n}\right)$ di masing-masing sumur, (a) Sumur-A menggunakan data FIT, (b) Sumur-B menggunakan data LOT.

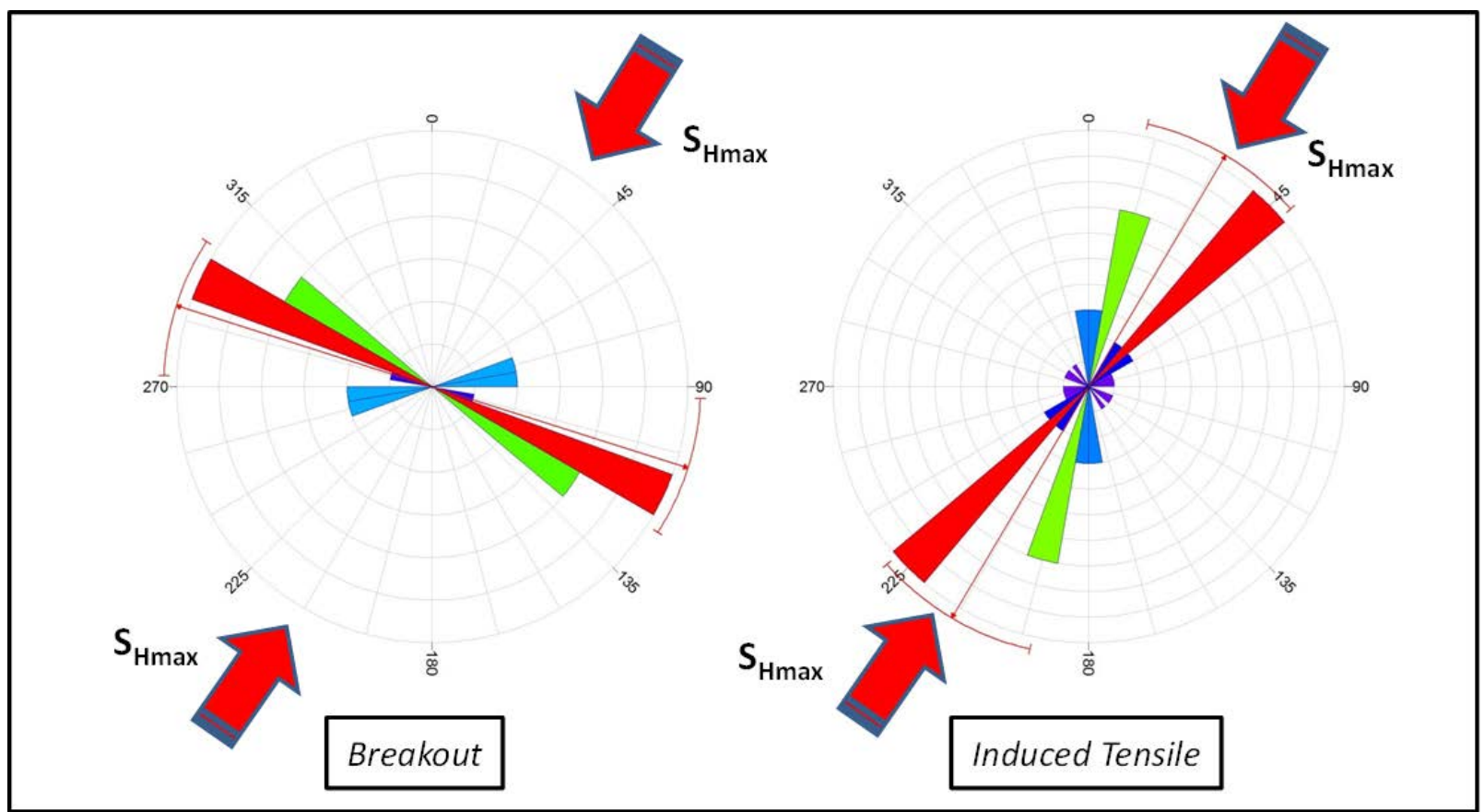

Gambar 12. Interpretasi arah tegasan horizontal maksimum $\left(\mathrm{S}_{\mathrm{Hmax}}\right)$ di Sumur-B. 
Persamaan ini digunakan pada 2 (dua) titik kedalaman di Sumur-B, yaitu 12.412 ftMD dan 11.696 ftMD. Nilai dari $S_{H \max }$ tersebut kemudian dimasukkan ke dalam polygon stress untuk mengetahui rezim tektonik yang bekerja di area sumur serta untuk memberikan interval nilai $\mathrm{S}_{\text {Hmax }}$ yang ada. Dari polygon stress diperoleh bahwa rezim tektonik yang bekerja di area tersebut adalah strike-slip, hal ini dikonfirmasi oleh posisi nilai LOT yang berada pada area strike-slip (Gambar 13).

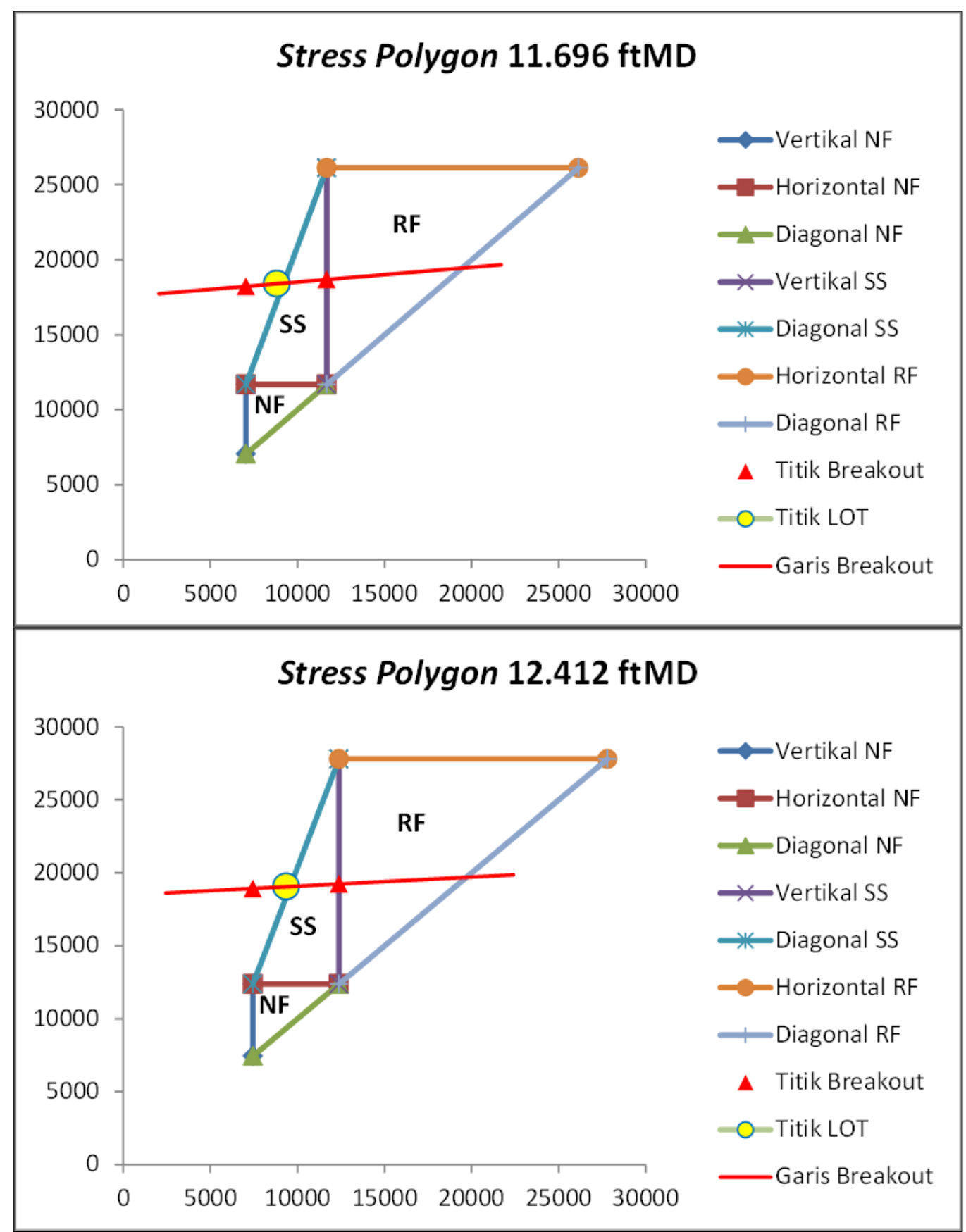

Gambar 13. Polygon stress pada kedalaman $11.696 \mathrm{ftMD}$ dan $12.412 \mathrm{ftMD}$ di Sumur-B. 


\section{Model Geomekanika}

Dalam penelitian ini, model geomekanika hanya dilakukan di Sumur-B, karena data yang dibutuhkan untuk melakukan analisis geomekanika hanya dimiliki oleh sumur ini, terutama data untuk batuan dasar.

Dari kurva geomekanika yang dihasilkan (Gambar 14) dapat dilihat bahwa garis $S_{\text {Hmax }}$ berada di paling kanan kemudian diikuti garis $\mathrm{S}_{\mathrm{v}}$, baru kemudian garis $\mathrm{S}_{\mathrm{hmin}}$ yang diperoleh dari data LOT. Dengan kata lain nilai $S_{\text {Hmax }}>S_{v}>S_{h m i n}$, sehingga rezim tektonik untuk area penelitian berdasarkan model geomekanika di atas adalah strikeslip. Hal ini konsisten terhadap hasil polygon stress yang menunjukkan bahwa garis rekahan breakout berada pada area strike-slip.

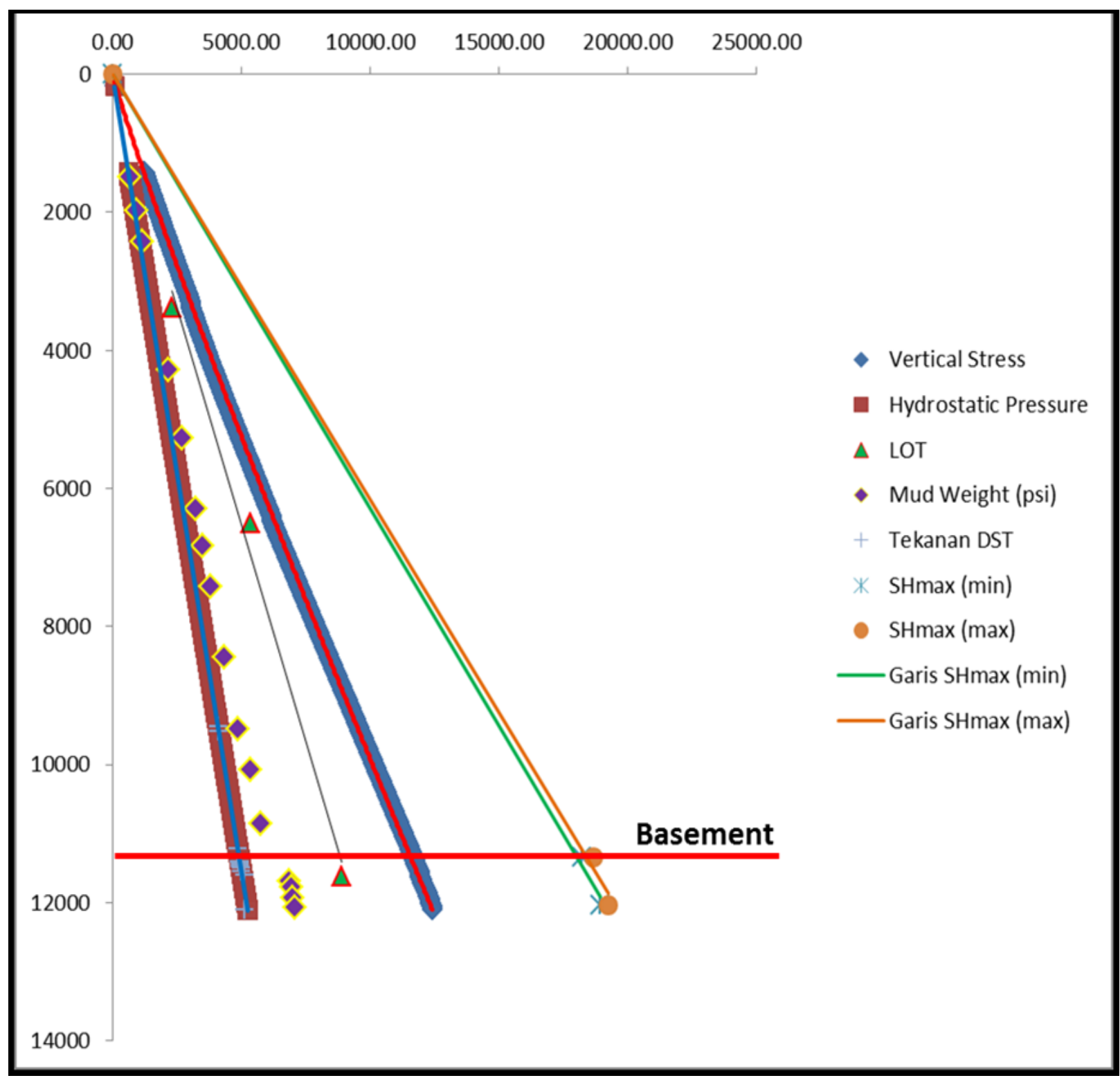

Gambar 14. Model geomekanika 1 (satu) dimensi di Sumur-B. 


\section{Tekanan Rekah Kritis}

Berdasarkan hipotesis tekanan kritis, rekahan atau sesar yang mempunyai rasio tegasan geser $(\tau)$ terhadap tegasan normal $\left(\sigma_{n}\right)$ lebih besar dari koefisien friksi geser, secara mekanik rekahan atau sesar tersebut aktif atau bergeser. Berdasarkan Barton dan Zoback (2002), rekahan yang dapat mengalirkan fluida adalah rekahan yang tekanannya dalam kondisi kritis (critically stressed fractures). Rekahan yang tekanannya dalam kondisi kritis ini cenderung untuk bergerak.
Metoda yang digunakan untuk melakukan analisis tekanan rekah kritis ini adalah Mohr-Coulomb Envelope. Data yang digunakan untuk membuat Mohr-Coulomb Envelope ini adalah data rekahan, parameter utama geomekanika $\left(S_{H m a x}, S_{h \text { min, }} S_{v}\right.$, tekanan pori), dan koefisien friksi $(\mu)$. Dengan menggunakan model geomekanika sebelumnya, hasil dari Mohr-Coulomb Envelope menujukkan bahwa sebagian kecil dari rekahan di Sumur-B dalam kondisi kritis (Gambar 15).

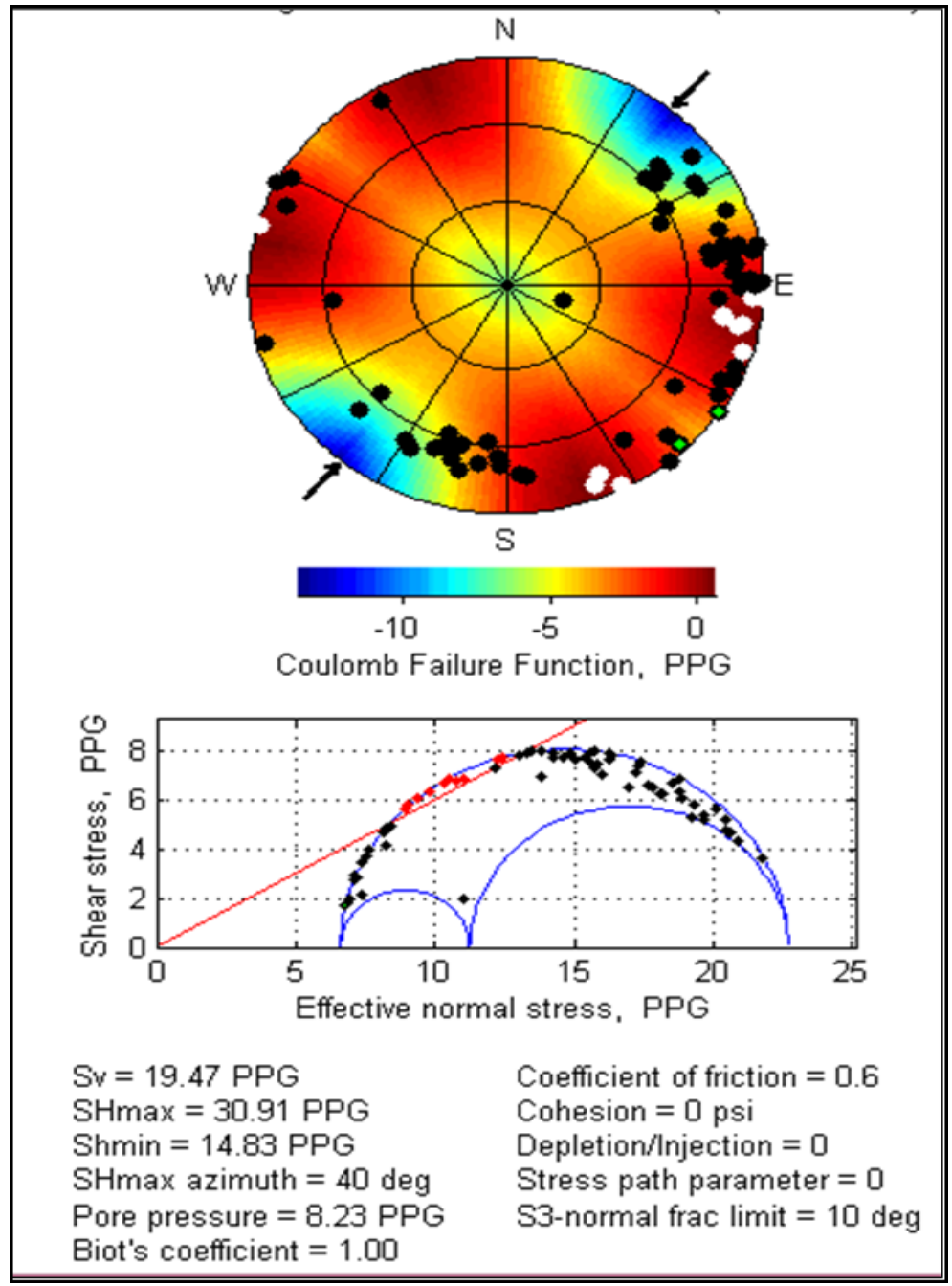

Gambar 15. Model tekanan rekah kritis pada Sumur-B. 
Koefisien friksi ( $\mu$ ) dalam analisis ini menggunakan asumsi 0,6, karena tidak ada tes laboratorium yang digunakan untuk mendapatkan nilai tersebut. Dalam penelitian ini juga coba dibuat perbandingan nilai koefisien friksi hubungannya dengan kondisi batuan yang stabil atau tidak stabil/kritis, hasilnya koefisien friksi 0,7 dan 0,8 memberikan kondisi rekahan yang stabil (di bawah Mohr-Coulomb Envelope), sedangkan koefisien friksi 0,6 memberikan sebagian kondisi rekahan yang dalam kondisi kritis (Gambar 16).
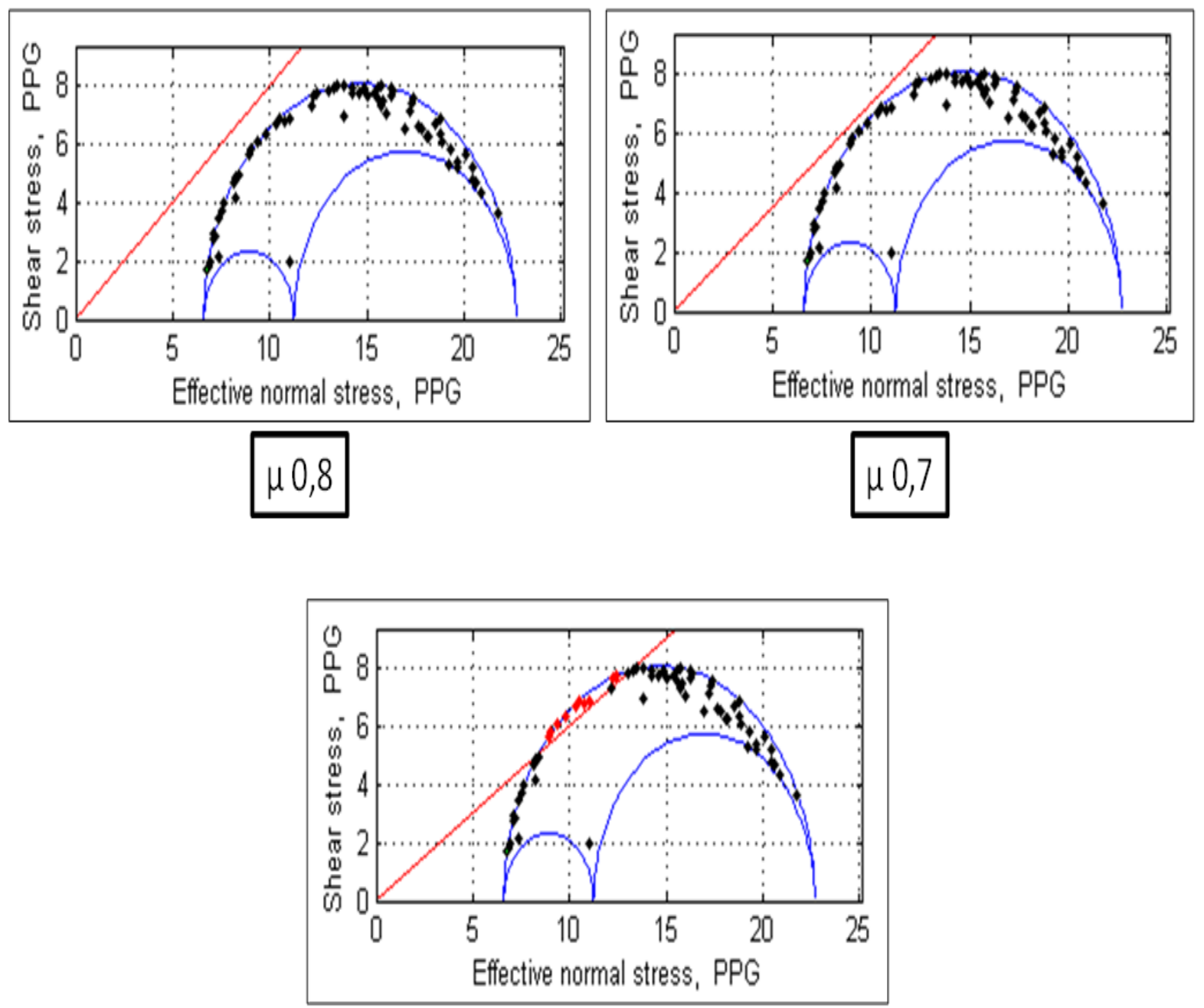

$\mu 0,6$

Gambar 16. Perbandingan nilai koefisien friksi $(\mu)$, pengaruhnya terhadap kondisi kritis batuan. 


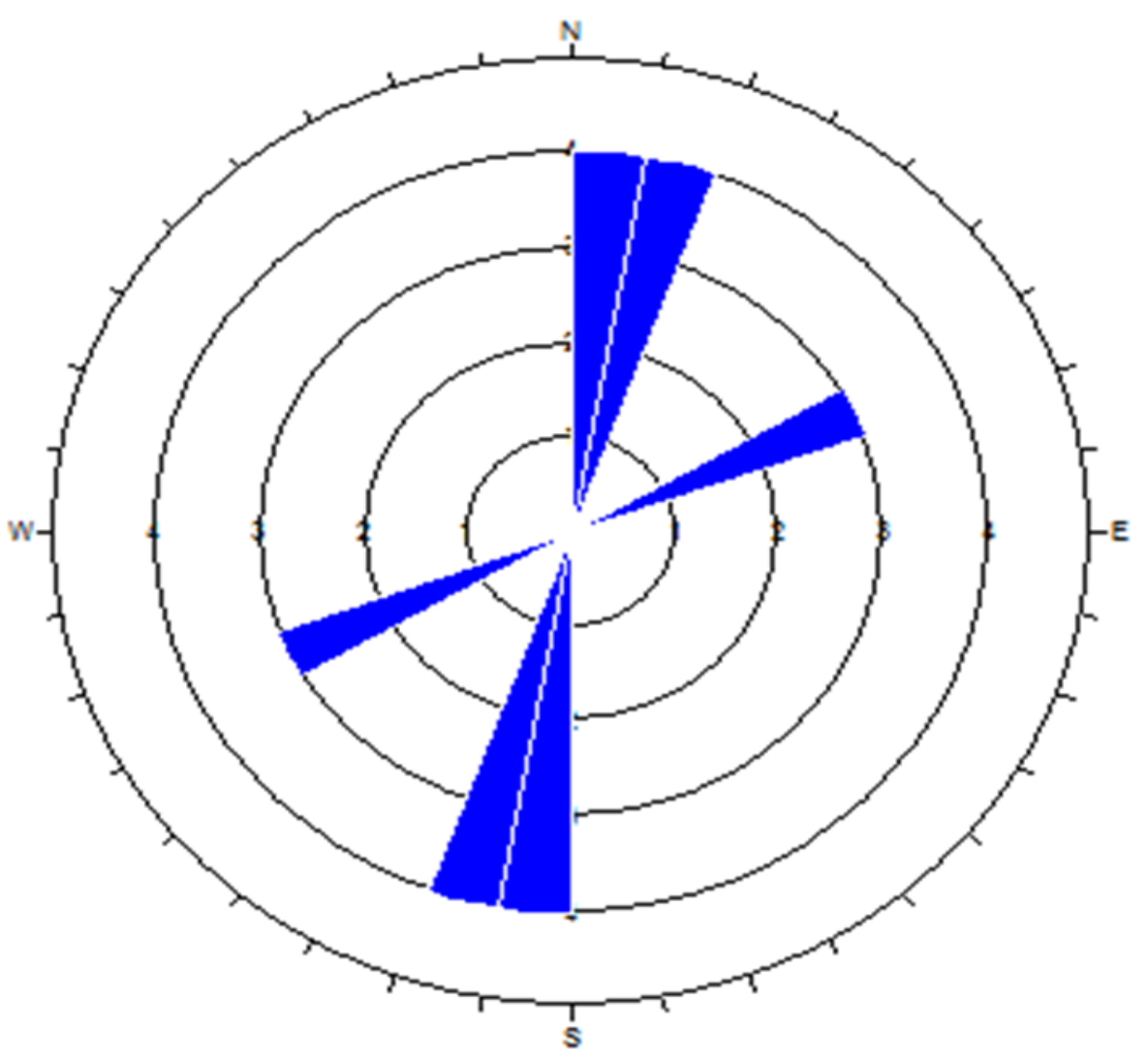

Gambar 17. Arah rekahan dalam kondisi tekanan kritis di Sumur-B.

Berdasarkan hasil analisisi tekanan rekah kritis tersebut, arah rekahan yang berada dalam kondisi kritis adalah relatif Timur laut-Barat daya (NE-SW), N 10 $-20^{\circ} \mathrm{E}$ dan $\mathrm{N} 65^{\circ} \mathrm{E}$ (Gambar 17).

\section{DISKUSI}

Nilai kekuatan batuan yang digunakan dalam model geomekanika sebaiknya menggunakan hasil dari percobaan laboratorium (UCS atau TCS). Hal ini guna mendapatkan nilai $S_{H \max }$ yang lebih mendekati kondisi sebenarnya. Penggunaan nilai kekuatan batuan dengan data dinamik (sonic, VSP, dsb) harus memperhitungkan tingkat kesalahan alat log pada saat melakukan akusisi. Selain nilai $\mathrm{C}_{0}$, dari hasil percobaan laboratorium juga akan diperoleh nilai koefisien friksi yang akan digunakan dalam analisis tekanan rekah kritis.

Data LOT yang akan digunakan sebagai nilai Shmin sebaiknya diperhatikan kembali, karena umumnya data yang digunakan sebagai nilai Shmin adalah nilai FCP (formation closure pressure) dari data extended leak-off test. Nilai FCP jika dilihat dari grafik akan sedikit lebih rendah dibandingkan nilai LOT, sehingga kemungkinan akan mempengaruhi analisis tekanan rekah kritis nantinya.

Rezim tektonik juga cukup penting untuk diketahui sebelum menggunakan data LOT sebagai nilai $\mathrm{S}_{\mathrm{hmin}}$, karena sampai saat ini masih menjadi perdebatan terkait data LOT 
digunakan untuk mencerminkan nilai $\mathrm{S}_{\mathrm{hmin}}$ atau $\sigma_{3}$ (least principal stress). Sehingga pada rezim tektonik strike-slip dan dalam kondisi yang didominasi oleh normal fault hal ini tidak menjadi perdebatan, karena posisi $S_{\text {hmin }}$ dan $\sigma_{3}$ adalah horizontal. Dalam kondisi yang didominasi oleh reverse fault, posisi $\sigma_{3}$ adalah vertikal sedangkan posisi $\mathrm{S}_{\mathrm{hmin}}$ harus tetap horizontal.

\section{KESIMPULAN}

Dari hasil penelitian tersebut terdapat beberapa hal yang dapat disimpulkan, yaitu:

1. Arah tegasan horizontal maksimum (S $\left.\mathrm{S}_{\text {max }}\right)$ berdasarkan hasil analisis di Sumur-B adalah relatif Timur laut-Barat daya (NNE-SSW), antara N 30 $-40^{\circ} \mathrm{E}$.

2. Berdasarkan hasil perhitungan parameter geomekanika pada Sumur-B, menujukkan

3. bahwa sumur tersebut berada dalam rezim sesar gesar (strike slip), yaitu $\mathrm{S}_{\mathrm{Hmax}}$ $>\mathrm{S}_{\mathrm{v}}>\mathrm{S}_{\mathrm{hmin}}$.

4. Berdasarkan hasil analisisi tekanan rekah kritis di Sumur-B, arah rekahan yang berada dalam kondisi kritis adalah relatif Timur Laut-Barat daya (NE-SW), N 10$20^{\circ} \mathrm{E}$ dan $\mathrm{N} 65^{\circ} \mathrm{E}$.

5. Berdasarkan hasil analisis tekanan rekah kritis tersebut, maka saran untuk pengeboran dengan target batuan dasar selanjutnya adalah pengeboran berarah yang tegak lurus dengan arah rekahan kritis tersebut.

\section{ACKNOWLEDGEMENTS}

Terima kasih atas bantuan, masukkan, dan koreksi baik dari rekan-rekan di Institut Teknologi Bandung, maupun rekan-rekan di Pertamina Hulu Energi West Madura Offshore.

\section{REFERENSI}

BULLETIN OF GEOLOGY, VOL. 1, NO. 1, 2017

DOI: 10.5614/bull.geol.2017.1.1.1
Adhyaksawan, R., (2003). Seismic facies and growth history of miocene carbonate platforms, wonocolo formation, North Madura Area, East Java basin, Indonesia, Proceedings Indonesian Petroleum Association, 29th Annual Convention \& Exhibition.

Barton, C.A., dan Zoback, M.D., (2002). Discrimination of Natural Fractures from Drilling-Induced Wellbore Failures in Wellbore Image DataImplication for Reservoir Permeability, SPE Reservoir Evaluation \& Engineering, June 2002.

Maulin, H. B., Armandita C., Mukti M. M., Mandhiri D., Rubyanto D., Romi S., (2012): Structural reactivation and its implication on exploration play: case study of JS-1 Ridge, Proceedings Indonesian Petroleum Association, 36th Annual Convention \& Exhibition.

Mudjiono, R., Pireno, G. E., (2001). Exploration of the North Madura Platform, offshore East Java, Indonesia, Proceedings Indonesian Petroleum Association, 28th Annual Convention \& Exhibition.

Prakasa, Y., (2003). Integrasi dan optimalisasi data sebagai dasar penyusunan model geologi dan karakteristik resevoir serta implikasinya pada formasi Ngrayong struktur Kawengan, Buletin Ikatan Ahli Teknik Perminyakan Indonesia, 39.

Satyana, A. H., Purwaningsih, M. E. M., (2003). Geochemistry of the East Java basin: new observations on oil grouping, genetic gas types and trends of hydrocarbon habitats, Proceedings Indonesian Petroleum 
Association, 29th Annual Convention \& Exhibition.

Sribudiyani, Muchsin, N., Ryacudu, R., Kunto, T., Astono, P., Prasetya, I., Sapiie, B., Asikin, S., Harsolumakso, A. H., Yulianto, I., (2003). The collision of the East Java microplate and its implication for hydrocarbon occurrences in the East Java basin, Proceedings Indonesian Petroleum Association, 29th Annual Convention \& Exhibition.

Zoback, M.D., (2007). Reservoir Geomechanics, New York: Cambridge University Press. 